\title{
Evaluation of Antioxidant and Antibacterial Properties of Magnolia champaca L. (Magnoliaceae) Stem Bark Extract
}

\author{
Md. Mahadi Hasan, Masuma Akter, Md. Ekramul Islam, \\ Md. Aziz Abdur Rahman and Mst. Shahnaj Parvin
}

Department of Pharmacy, University of Rajshahi, Rajshahi-6205, Bangladesh

(Received: January 10, 2020; Accepted: June 26, 2020; Published: July 25, 2020)

\begin{abstract}
The current study was designated to explore the antioxidant and antibacterial properties of the methanolic extract of Magnolia champaca stem bark and its different fractions. Antioxidant activity was assessed using total antioxidant capacity, ferric reducing power, DPPH, hydroxyl and hydrogen peroxide scavenging assay. Antibacterial activity was evaluated against five gram positive and five gram negative bacteria using disc diffusion assay method. Among the different fractions, chloroform fraction (CHF) and ethyl acetate fraction (EAF) showed the highest antioxidant activity whereas aqueous fraction (AQF) showed lowest activity in DPPH radical scavenging assay with $\mathrm{IC}_{50}$ of 12.12, 22.41 and 55.16 $\mu \mathrm{g} / \mathrm{ml}$, respectively. Both of the extracts CHF and EAF also exhibited highest total antioxidant capacity, ferric reducing power and hydrogen peroxide scavenging activity with concentration dependent manner when compared to standard BHT. Moderate to potent antibacterial activity was observed against all tested organisms compared to standard azithromycin. The results from the present study revealed that the different fractions of stem bark of $M$. champaca specially CHF and EAF possess antioxidant and antibacterial property which support its use in traditional medicine and suggesting that the plant may be further investigated to discover its pharmacologically active natural products.
\end{abstract}

Key words: Magnolia champaca, Magnoliaceae, stem bark, antioxidant, BHT, antibacterial, azithromycin.

\section{Introduction}

These universe is full of medicinal plants which are a source of biologically active compounds having therapeutic properties and have been used different class of people for the remedy of various ailments (Biswas et al., 2010). These plants play a considerable role in discovery and development of new therapeutic agents for the maintenance of human health from the very early days of human civilization (Howladeret al., 2011).

M. champaca, (family Magnoliaceae) commonly known as Champak, is a large evergreen tree and is widely distributed in Bangladesh, eastern SubHimalayan tract, Myanmar, India and China (Shrestha et al., 2000). The genus Magnolia is an ancient genus comprises about 200 flowering plant species (Azuma et al., 1996). Many of these plants are medicinally important and are used in traditional medicines especially in the Far East (Namba, 1980). A variety of secondary metabolites including alkaloids, flavonoids, lignans, neolignans and terpenoids have been reported from the genus (Sarkeret al., 2002). The plant M. champaca have been reported to exhibit diuretic (Ahmad et al., 2011), antidiabetic (Jaraldet al., 2008; and Gupta et al., 2011), anti-inflammatory (Vimalaet al., 1997), burn wound healing (Shanbhag et al., 2011) and analgesic (Mohamed et al., 2009) activities. Traditionally, the plant is used in the treatment of a wide range of diseases including fever, colic, leprosy, cough and rheumatism and for remedies of various disorders (Perry et al., 1980; and Hasan et al., 2009).

Corresponding author: Mst. Shahnaj Parvin shahnaj_parvin@ru.ac.bd

DOI: https://doi.org/10.3329/bpj.v23i1.48328 
By considering the ethnomedicinal and previously reported activities, the current study was designed to evaluate the antioxidant and antibacterial effects of the stem barkof $M$. champaca.

\section{Materials and Methods}

Plant collection and identification: The stem bark of M. champaca was collected from Rajshahi University campus in November, 2018 and was authenticated by the authority of Bangladesh National Harberium (DACB ACCESSION NUMBER-48087). The collected stem bark was washed with water, sun dried for 7 days and finally dried in an electric oven at $40^{\circ} \mathrm{C}$ for 72 hours. The dried materials were then ground into coarse powder with the help of a grinder (FFC15, China) and stored at room temperature in an airtight container for further use.

Extraction and fractionation: Dried powdered stem bark $(1.25 \mathrm{~kg})$ was taken in amber colored extraction bottles and soaked in methanol (5 L). The bottles with its contents were sealed and kept for a period of about 12 days with occasional shaking. At the end of specific period, the whole mixtures were filtered through cotton and then Whatman No.1 filter paper and were concentrated with a rotary evaporator under reduced pressure at $40^{\circ} \mathrm{C}$ temperature to afford crude methanol extract (CME). The concentrated CME was further fractionated into n-hexane (NHF), chloroform (CHF), ethyl acetate (EAF) and finally aqueous (AQF) fraction by modified Kupchan method.

\section{Antioxidant activity assay}

Determination of total antioxidant capacity: The total antioxidant capacity of CME, NHF, CHF, EAF, $\mathrm{AQF}$ and standard BHT was determined spectrophotometrically by phosphomolybdenum method described by Prieto et al. (1999). The phosphomolybdenum method is based on the reduction of Mo (VI) to Mo (V) by the antioxidant compound and the formation of green phosphate-Mo (V) complex with a maximal absorption at $695 \mathrm{~nm}$. In brief, $0.3 \mathrm{ml}$ of each sample at various concentration $(6.25,12.5,25,50$ and $100 \mu \mathrm{g} / \mathrm{ml})$ was mixed with $3 \mathrm{ml}$ reagent solution $\left(0.6 \mathrm{M} \mathrm{H}_{2} \mathrm{SO}_{4}, 28\right.$ $\mathrm{mM}$ Sodium phosphate and $4 \mathrm{mM}$ Ammonium molybdate). The blank solution contained methanol only. The mixtures were incubated at $90^{\circ} \mathrm{C}$ for 90 minutes and the absorbance of the each solution was measured at $695 \mathrm{~nm}$ against blank solution. Increased absorbance of the reaction mixture indicated increase total antioxidant capacity.

Ferric reducing power assay: The ferric reducing power assay of extracts and BHT was evaluated by the method of Oyaizu (1986). Various concentrations $(6.25-100 \mu \mathrm{g} / \mathrm{ml})$ of samples/BHT in $1 \mathrm{ml}$ of distilled water were mixed with phosphate buffer (2.5 ml, 0.2 M, pH 6.6) and potassium ferricyanide $(2.5 \mathrm{ml}, 1 \%)$. The mixture was incubated at $50^{\circ} \mathrm{C}$ for 20 minutes to complete the reaction. Then $2.5 \mathrm{ml}$ of trichloroacetic acid (10\%) was added into the test tube. The whole mixture was centrifuged at $1000 \mathrm{rpm}$ for 10 minutes. Finally, $2.5 \mathrm{ml}$ of supernatant was mixed with distilled water $(2.5 \mathrm{ml})$ and ferric chloride $(1 \mathrm{ml}, 0.1 \%)$ and the absorbance was measured at $700 \mathrm{~nm}$. Increased absorbance of the mixture is an indication of an increase of reduction capability.

DPPH radical scavenging activity: DPPH free radical scavenging activity of the extracts was performed by the method described by Braca et al. (2001) with slight modifications. $0.1 \mathrm{ml}$ of extracts (concentration range: 3.125 to $100 \mu \mathrm{g} / \mathrm{ml}$ ) were added to $3 \mathrm{ml}$ of $0.004 \% \mathrm{w} / \mathrm{v}$ DPPH solution (in methanol). The mixture was vortex thoroughly and left in the dark at room temperature for 30 minutes. The absorbance of the mixture was measured spectrophotometrically at $517 \mathrm{~nm}$ using methanol, DPPH solution and BHT as blank, control and standard, respectively. DPPH scavenging activity was calculated as: $\%$ scavenging $=\left[\left(\mathrm{A}_{0}-\mathrm{A}_{1}\right) / \mathrm{A}_{0}\right] \times 100$, where $A_{0}$ was the absorbance of the control and $A_{1}$ was the absorbance of the sample/standard. The $\mathrm{IC}_{50}$ was calculated from percentage scavenging versus concentration curve by linear regression analysis.

Hydroxyl radical scavenging assay: The hydroxyl radical scavenging assay was determined by 
the method of Halliwell et al. (1987). $1 \mathrm{ml}$ of the reaction mixture consists of $100 \mu \mathrm{l}$ of 2-deoxy-Dribose $\left(28 \mathrm{mM}\right.$ in $20 \mathrm{mM} \mathrm{KH} \mathrm{KO}_{4}-\mathrm{KOH}$ buffer, $\mathrm{pH}$ 7.4), $500 \mu \mathrm{l}$ of samples (different concentrations), $100 \mu \mathrm{l}$ of EDTA $(1.04 \mathrm{mM}), 100 \mu \mathrm{l}$ of $200 \mu \mathrm{M} \mathrm{FeCl}_{3}$ $(1: 1 \mathrm{v} / \mathrm{v}), 100 \mu \mathrm{l} \mathrm{H}_{2} \mathrm{O}_{2}(1 \mathrm{mM})$ and $100 \mu \mathrm{l}$ ascorbic acid $(1 \mathrm{mM})$ was incubated at $37^{\circ} \mathrm{C}$ for 1 hour. $1 \mathrm{ml}$ of thiobarbituric acid (1\%) and $1 \mathrm{ml}$ of trichloroacetic acid $(10 \%)$ were added to it and further incubated at $100^{\circ} \mathrm{C}$ for 20 minutes. After cooling, absorbance was measured at $532 \mathrm{~nm}$ against a blank containing deoxy-D-ribose and buffer. The percentage of scavenging activity was calculated by: $\%$ scavenging $=\left[\left(\mathrm{A}_{0}-\mathrm{A}_{1}\right) / \mathrm{A}_{0}\right] \times 100$, where $\mathrm{A}_{0}=$ the absorbance of the control and $\mathrm{A}_{1}=$ the absorbance of the sample/standard BHT. The percentage of scavenging was plotted against concentration and $\mathrm{IC}_{50}$ was calculated from the graph.

Hydrogen peroxide scavenging activity: Hydrogen peroxide scavenging activity was determined by replacement titration method described by Zhang (2000). Aliquot of $1 \mathrm{ml} \mathrm{H}_{2} \mathrm{O}_{2}$ $(0.1 \mathrm{mM})$ and $1 \mathrm{ml}$ of samples (concentration: 100 and $200 \mu \mathrm{g} / \mathrm{ml}$ ) were mixed, followed by 2 drops of $3 \%$ ammonium molybdate, $10 \mathrm{ml} \mathrm{H}_{2} \mathrm{SO}_{4}(2 \mathrm{M})$ and 7 $\mathrm{ml} \mathrm{KI}(1.8 \mathrm{M})$. The mixed solution was titrated with sodium thiosulphate $(5.09 \mathrm{mM})$ until yellow color disappeared. The percentage of scavenging of hydrogen peroxide was calculated as: $\%$ of scavenging $=\left[\left(\mathrm{V}_{0^{-}}-\mathrm{V}_{1}\right) / \mathrm{V}_{0}\right] \times 100$ where $\mathrm{V}_{0}$ was the volume of sodium thiosulphate solution used to titrate the control sample in the presence of $\mathrm{H}_{2} \mathrm{O}_{2}$ and $\mathrm{V}_{1}$ was the volume of sodium thiosulphate solution used in the presence of sample/standard.

\section{Antibacterial activity assay}

Microorganisms: The following bacteria strains were used: Gram $(+)=$ Bacillus cereus, Bacillus subtilis, Staphylococcus aureus, Staphylococcus brodie, Staphylococcus epidermidisand Gram (-) = Escherichia coli, Shigelladysenteriae,Proteus mirabilis, Proteus vulgaris, Pseudomonas aeruginosa. Bacteria strains were maintained on nutrient agar slants at $4^{\circ} \mathrm{C}$ in Department of Pharmacy, RU.
Disc diffusion method: The agar disc diffusion method (Bonevet al., 2008 and Razmavar et al., 2014) was used for the determination of antibacterial activity of the extract and different fractions of $M$. champaca stem bark against five gram (+) and five gram (-) bacteria. A stock solution of sample was prepared by dissolving the sample in methanol. A suspension of the microorganism was spread on the solid media plates. Whatman filter paper discs $(6 \mathrm{~mm}$ in diameter) were soaked with $10 \mu \mathrm{l}$ of the test sample (300 $\mu \mathrm{g} /$ disc concentration) and placed on the inoculated media. Methanol loaded discs were used as negative control and azithromycin (AZM 30) antibiotic discs were used as positive control. Plates were kept at $4^{\circ} \mathrm{C}$ for 2 hours for proper diffusion and then incubated at $37^{\circ} \mathrm{C}$ for 24 hours. Antibacterial activity was evaluated by measuring the diameter $(\mathrm{mm})$ of the inhibition zone around the discs.

\section{Results and Discussion}

\section{Antioxidant activity assay}

Total antioxidant capacity: The total antioxidant capacity of the CME and its four fractions NHF, CHF, EAF and AQF was assessed by phosphomolybdenum method and compared with reference standard BHT. All the extracts showed total antioxidant activity in a concentration dependent manner (Figure 1). Total antioxidant capacity of $\mathrm{CME}$ and fractions were ranked as follows: CHF > $\mathrm{EAF}>\mathrm{CME}>\mathrm{AQF}>\mathrm{NHF}$. At the concentration of $100 \mu \mathrm{g} / \mathrm{ml}$ highest absorbance was found in CHF $(1.205 \pm 0.029)$ and $\operatorname{EAF}(0.764 \pm 0.032)$. On the other hand, CME $(0.565 \pm 0.019)$ showed moderate activity and AQF $(0.479 \pm 0.013)$, and NHF $(0.317 \pm$ 0.002 ) showed mild activity as compared to reference standard BHT (1.996 \pm 0.027). The results demonstrated that the chloroform fraction (CHF) exhibited similar total antioxidant capacity to that of reference BHT and higher capacity than the crude methanolic extract and other fractions tested. NHF showed the least activity among the fractions. The total antioxidant capacity of the samples was found to be varied in different solvent fractions. The difference in the amount of antioxidant of these 
samples may be attributed to the differences in the amount and types of antioxidant compounds present in the extractives.

Ferric reducing power assay: It has been reported that there is a direct correlation between antioxidant activities and reducing power of certain plant extracts. The reducing properties are generally associated with the presence of reductants, which have been shown to exert antioxidant action by breaking the free radical chain by donating a hydrogen atom. In this assay, the presence of reductants in the antioxidant sample causes the reduction of the $\mathrm{Fe}^{3+}$ - ferricyanide complex to the $\mathrm{Fe}^{2+}$ - ferricyanide form, and reducing power is monitored by measuring the formation of Perl's Prussian blue at $700 \mathrm{~nm}$. The reducing power of all the samples increased gradually with the increase in concentrations of the samples (Figure 1). At a concentration of $100 \mu \mathrm{g} / \mathrm{ml}$, maximum absorbance were found in CHF $(1.266 \pm 0.044)$ and EAF $(0.831$ $\pm 0.027)$. On the other hand, CME $(0.624 \pm 0.024)$, $\mathrm{AQF}(0.620 \pm 0.017)$ and NHF $(0.522 \pm 0.007)$ showed moderate activity as compared to reference standard BHT $(1.544 \pm 0.049)$. CHF showed the highest reducing activity than other fractions followed by EAF, CME, AQF and NHF. The reducing capacity of $\mathrm{CHF}$ is similar to that of standard BHT and highest among all the tested extractives. We speculate that the reducing power of CHF is likely due to the presence of phenolic compounds, which could act as electron donors.

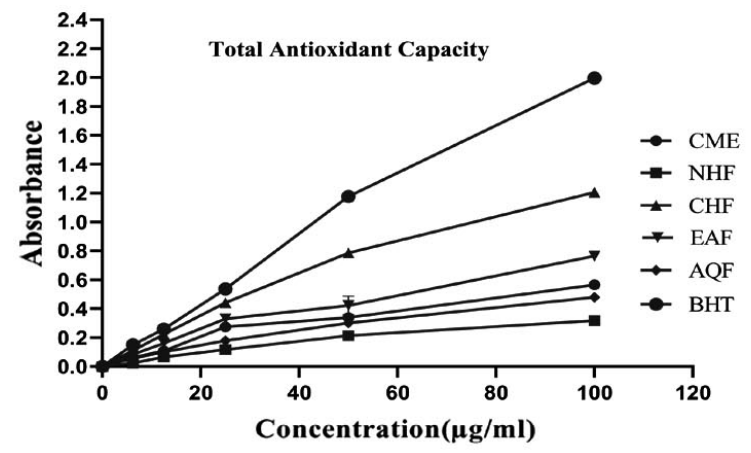

$D P P H$ radical scavenging activity: In the model of scavenging, the stable DPPH radical is the most widely used method to evaluate antioxidant activities of various samples including plant extract. When DPPH accepts an electron donated by an antioxidant compound, the DPPH purple color solution is decolorized, which can be quantitatively measured from the change in absorbance and \% scavenging activity is calculated. The scavenging activity is increased by increasing the concentration of the sample extract. 50\% inhibition $\left(\mathrm{IC}_{50}\right)$ is calculated from the graph plotted inhibition percentage versus concentration by linear regression analysis. The $\mathrm{IC}_{50}$ values of $\mathrm{CME}, \mathrm{NHF}, \mathrm{CHF}, \mathrm{EAF}$ and $\mathrm{AQF}$ were 29.74, 44.56, 12.12, 22.41 and $55.13 \mu \mathrm{g} / \mathrm{ml}$, respectively (Figure 2). Thesmaller is the $\mathrm{IC}_{50}$ values, the higher is the antioxidant activity of the plant extractives. Therefore, the CHF demonstrated highest scavenging activity followed by EAF, CME and NHF and the $\mathrm{AQF}$ showed the lowest scavenging activity. The $\mathrm{IC}_{50}$ value of standard BHT was $6.71 \mu \mathrm{g} / \mathrm{ml}$.

Hydroxyl radical scavenging assay: In the hydroxyl radical scavenging assay, the ability of the crude methanol extract and its four fractions to remove the formed hydroxyl radical in solution was evaluated quantitatively and compared with the reference standard BHT. The scavenging activity $\left(\mathrm{IC}_{50}\right)$ of $\mathrm{CHF}, \mathrm{EAF}, \mathrm{CME}, \mathrm{AQF}$ and $\mathrm{NHF}$ were found to be 21.09, 35.14, 43.14, 52.58, and 62.86 $\mu \mathrm{g} / \mathrm{ml}$, respectively, indicating the highest activity of $\mathrm{CHF}$ when compared to the standard BHT with $\mathrm{IC}_{50}$ of $9.98 \mu \mathrm{g} / \mathrm{ml}$ (Figure 2).

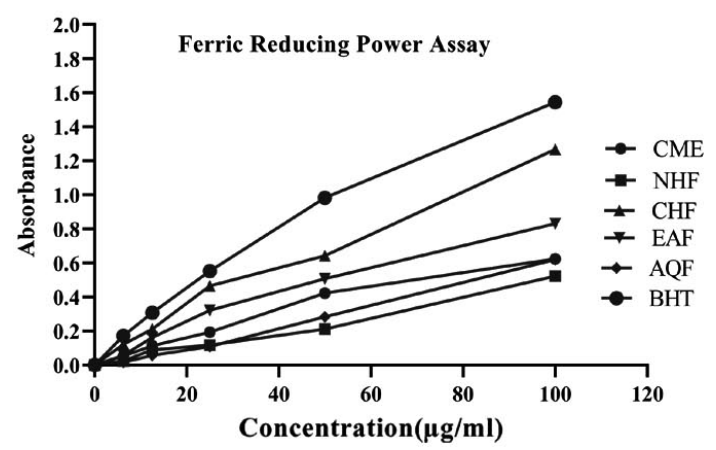

Figure 1. Total antioxidant capacity and ferric reducing power of CME and fractions of $M$. champaca stem bark. 

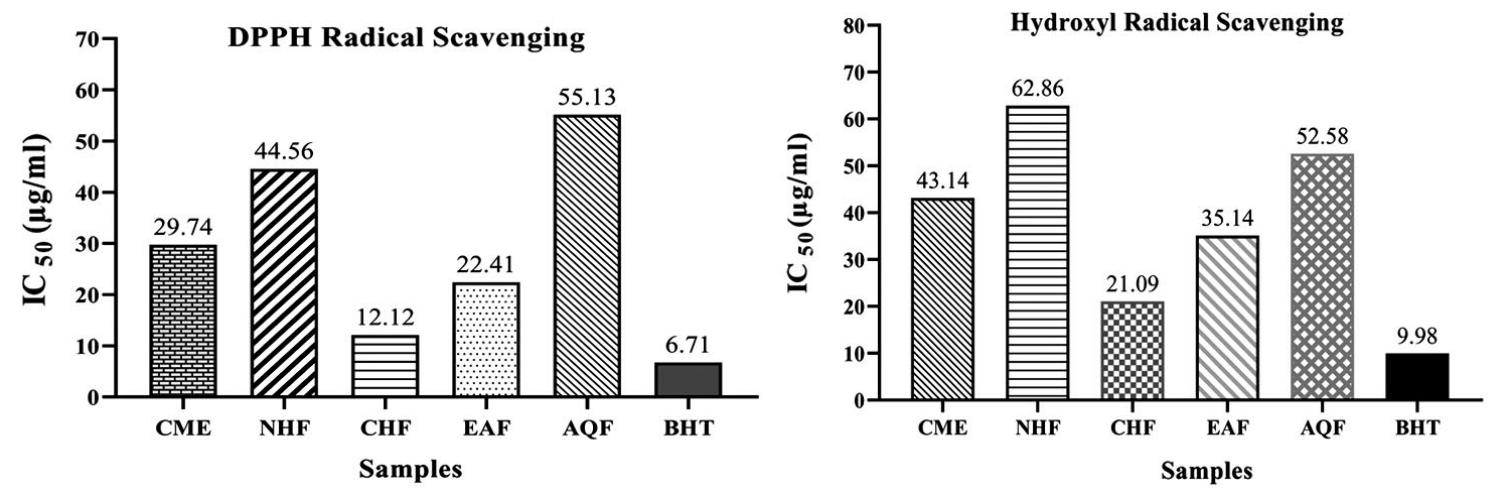

Figure 2. DPPH and hydroxyl radical scavenging activity of CME and fractions of M. champaca stem bark.

Hydrogen peroxide scavenging activity: The crude methanolicextract and different fractions of the plant demonstrated $\mathrm{H}_{2} \mathrm{O}_{2}$ scavenging activity in a concentration dependent manner. At a concentration of 100 and $200 \mu \mathrm{g} / \mathrm{ml}$ CME, NHF, CHF, EAF and AQF showed 19.70, 13.62, 39.38, 30.58 and 11.20 $\%$ and $45.45,26.65,65.45,54.22$ and $20.29 \%$, scavenging activity, respectively), while the values for standard BHT was 63.04 and $80.01 \%$ (Figure 3). The result showed that different fractions of methanolic extract of the plant possess moderate hydrogen per oxide scavenging activity.

\section{Antibacterial activity:}

The crude methanolic extract and its four fractions were investigated to evaluate their antibacterial activity against five Gram positive and five Gram negative bacterial strains using disc diffusion method where standard azithromycin was used for comparison (Table 1 and Figure 4). Maximum zone of inhibition (24 mm) was observed by CHF against Staphylococcus epidermidis and Shigella dysenteriae. CHF (22 mm), NHF (21 mm) and EAF $(20 \mathrm{~mm})$ showed maximum zone of inhibition against Bacillus cereus, Staphylococcus

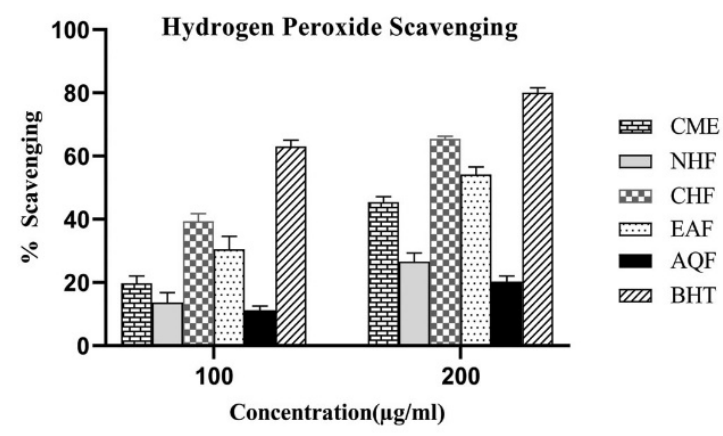

Figure 3. Hydrogen peroxide scavenging activity of crude extract and fractions of $M$. champaca stem bark.

Table 1. Antibacterial activity (zone of inhibition, mm) of CME and various fractions of $M$. champaca stem bark.

\begin{tabular}{llcccccc}
\hline & & \multicolumn{5}{c}{ Zone of Inhibition $(\mathrm{mm})$} \\
\cline { 3 - 7 } & Bacteria strains & CME & NHF & CHF & EAF & AQF & $\begin{array}{c}\text { Azithromycin } \\
(30 \mu \mathrm{g} / \mathrm{disc})\end{array}$ \\
\hline \multirow{3}{*}{ Gram } & Bacillus cereus & 16 & 9 & 22 & 18 & 8 & 37 \\
Positve & B. subtilis & 11 & 14 & 19 & 20 & 16 & 38 \\
& Staphylococcus aureus & 10 & 12 & 13 & 17 & 11 & 24 \\
& Stap. brodie & 13 & 21 & 12 & 10 & 14 & 35 \\
& Stap. epidermidis & 8 & 14 & 24 & 19 & 9 & 36 \\
Gram & Escherichia coli & 15 & 17 & 16 & 14 & 11 & 29 \\
& Shigella dysenteriae & 14 & 11 & 24 & 16 & 10 & 27 \\
& Proteus mirabilis & 12 & 8 & 13 & 9 & 7 & 22 \\
& P. vulgaris & 11 & 13 & 19 & 12 & 13 & 23 \\
& Pseudomonas aeruginosa & 14 & 12 & 18 & 16 & 11 & 22 \\
\hline
\end{tabular}



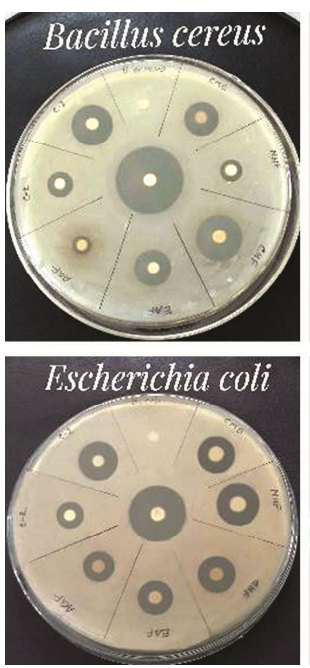

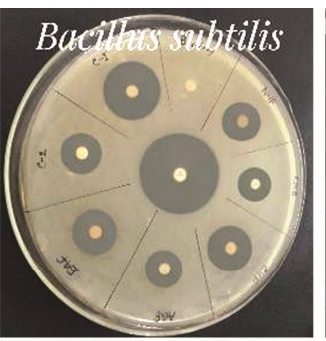

Shigelladusenteriae

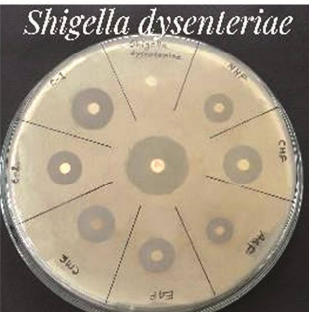

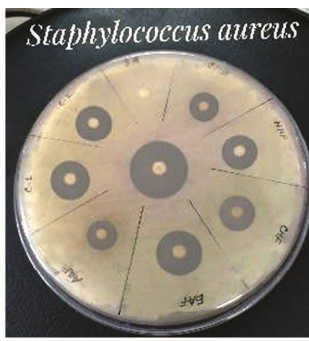

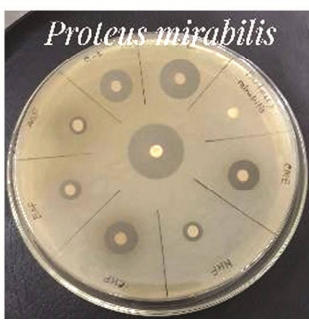

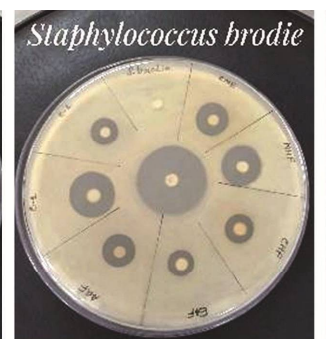

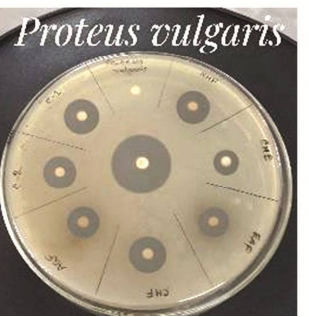

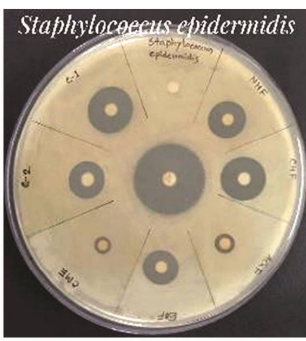

Pseudomonas aenuginosit

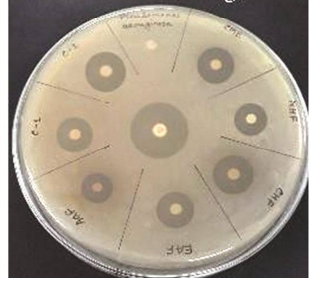

Figure 4. Zone of inhibition of the extract and fractions against the tested microorganisms.

brodieand Bacillus subtilis, respectively. Crude methanolic extract and other fractions also showed moderate to potent activity against all organisms. The results revealed that all plant extract and fractions were potentially effective in suppressing microbial growth of bacteria with variable potency. Results of antimicrobial activity of the investigated plant extracts suggested that Proteus mirabilis was the most resistant strain to plant extracts followed by other strains. From the study it has been found that the fractions might have some compounds, which are responsible for the antibacterial activity.

\section{Conclusion}

According to the present observations, it can be concluded that the plant extracts have significant antioxidant and antibacterial activity. The results justify the traditional use of $M$. champacain the health care system. So the investigated plant could be the source of several nutraceuticals for managing many degenerative diseases such as neurodegenerative diseases, cancer, diabetes etc. However, further studies are still required to explore the phytoconstituents responsible for its activity and to elucidate the molecular mechanism underlying the effects of the plant extract as an antioxidant and antibacterial agent.

\section{References}

Ahmad, H., Sexena, V., Mishra, A. and Gupta, R. 2011. Diuretic activity of aq. extract of $M$. champaca Linn. leaves and stem bark in rats. Newsletter. 2, 568-574.

Biswas, A., Bari, M.A., Roy, M. and Bhadra, S.K. 2010. Inherited Folk pharmaceutical knowledege of tribal people in the Chittagong Hill tracts, Bangladesh. Indian J. Trad. Knowledge. 9, 77-89.

Bonev, B., Hooper, J. and Parisot, J. 2008. Principles of assessing bacterial susceptibility to antibiotics using the agar diffusion method. J. Ant. Chem. 61, 12951301.

Braca, A., De Tommasi, N., Di Bari, L., Pizza, C., Politi, M. and Morelli, I. 2001. Antioxidant Principles from Bauhinia tarapotensis. J. Nat. Prod. 64, 892-895.

Gupta, S., Mehta, K., Chauhan, D., Kumar, S. and Nair, A. 2011. Morphological changes and antihyperglycemic effect of Micheliachampacaleaves extract on $\beta$ - cell in Alloxan-induced diabetic rats. Recent. Res. Sci. Tech. 3, 81-87.

Hasan, S.M.R., Hossain, M.M., Akhter, R., Jamila, M., Mazumdar, M.E.H. and Rahman, S. 2009. DPPH free radical scavenging activity of some Bangladeshi medicinal plants. J. Med. Plants Res. 3, 875-879.

Halliwell, B., Gutteridge, J. M. C. and Aruoma, O. I. 1987. The deoxyribose method: a simple "test-tube" assay for determination of rate constants for reactions of hydroxyl radicals. Analyt. Biochem. 165, 215-219. 
Howlader, M.A., Rizwan F., Sultana, S., Rahman, M.R., Shams-Ud-Doha, K.M., Mowla, R. and Apu, A.S. 2011. Antimicrobial, antioxidant and cytotoxic effects of methanolic extracts of leaves and stems of Glycosmispentaphylla (Retz.). J. Applied Pharm. Sci. 1, 137-140.

Jarald, E.E., Joshi, S.B. and Jain, D.C., 2008. Antidiabetic activity of flower bud of Micheliachampaca. Indian J. Pharmacol. 40, 256-260.

Mohamed, H.M., Jahangir, R., Hasan, S.M.R., Akter, R., Ahmed, T., Islam, M.I. and Faruque, A. 2009. Antioxidant, analgesic and cytotoxic activity of Micheliachampacaleaf. Stamford J. Pharma. Sci. 2, 17.

Oyaizu, M. 1986. Studies on Products of Browning Reactions: Antioxidative activities of product of browning reaction prepared from glucosamine. Japan J. Nutri. 44, 307-315.

Perry, L.M. 1980. Medicinal plants of East and Southeast Asia: attributed properties and uses Cambridge, Massachusetts, and London: The MIT Press. 154

Press, J.R., Shrestha, K.K. and Sutton, D.A. 2000. Annotated checklist of the flowering plants of Nepal Michelia (Magnolia) champaca. London: Natural History Museum.
Prieto, P., Pineda, M., and Aguilar, M. 1999. Spectrophotometric quantitation of antioxidant capacity through the formation of a phosphomolybdenum complex: Specific application to the determination of Vitamin E. Analyt. Biochem. 269, 337-341.

Razmavar, S., Abdulla, M. A., Ismail, S. B. and Hassandarvish, P. 2014. Antibacterial activity of leaf extracts ofBaeckeafrutescensagainst methicillinresistant Staphylococcus aureus. BioMed Reach. Int. $1-5$.

Sarker, S.D., Latif, Z., Stewart, M. and Nahar, L. 2002. Phytochemistry of the genus Magnolia. In: Sarker, S.D. and Maruyama, Y. editors. The genus Magnolia.C.R.C. Press. pp. 32-85

Shanbhag, T., Kodidela, S., Shenoy, S., Amuthan, A., and Kurra, S. 2011. Effect of Michelia champaca Linn. flowers on burn wound healing in Wister Rats. Int. J. Pharma. Sci. 7, 112-115.

Vimala, R., Nagarajan, S., Alam, M., Susan, T. and Joy, S. 1997. Anti-inflammatory and antipyretic activity of Michelia champaca (White variety), Ixora brachiata Roxb. and Rhynchosia Cana (Willd.) D.C. flower extract. Indian J. Exp. Biol. 35, 1310-1314.

Zhang, X.Y. 2000. Principles of chemical analysis, Beijing, China: China Sci. Press. pp. 275-276. 